\title{
Needle Biopsy
}

National Cancer Institute

\section{Source}

National Cancer Institute. Needle Biopsy. NCI Thesaurus. Code C15190.

The removal of a tissue sample using a needle, for microscopic examination. 